\title{
Heredity Mode of Onion (Allium cepa L.) Bulb Shape Index
}

\author{
Nenad Pavlović ${ }^{*}$. Milan Zdravković1 · Jelica Gvozdanović-Varga ${ }^{2}$. \\ Jelena Mladenović ${ }^{3}$ - Radoš Pavlović ${ }^{3}$ Jasmina Zdravković \\ ${ }^{1}$ Institute for Vegetable Crops, Karađorđeva 71, 11420 Smederevska Palanka, Serbia \\ ${ }^{2}$ Institute of Field and Vegetable Crops, Maksima Gorkog 30, 21000 Novi Sad, Serbia \\ ${ }^{3}$ University of Kragujevac, Faculty of Agronomy Čačak, Cara Dušana 34, 32000 Čačak, Serbia
}

\begin{abstract}
Summary: Onion (Allium cepa L.) is a very important and widespread vegetable crop. Bulb shape index is a very significant biological and commercial trait. Bulb shape impacts the price, processing, resistance to diseases, etc., which is the reason why it is a very important economical trait. Success of the breeding process depends on genetic determination of the traits that were targeted in the selection process. In order to assess the genetic determination of bulb shape index, the trial was set up in the random block system with five replications, with diallel crossing without reciprocals. Bulb shape index in $\mathrm{F}_{1}$ generation was from flat-round to oval shaped. The most common heredity mode of the bulb shape index was superdomination. The highest value of GCA for shape index was found in 'Makol bronzi', which was the indicator of the best combining abilities. The highest SCA in $\mathrm{F}_{1}$ and $\mathrm{F}_{2}$ generation was found in the hybrid 'Makoi bronzi' $\times$ 'AC 101'.
\end{abstract}

Key words: bulb shape index, heredity mode, onion

\section{Introduction}

Onion (Allium cepa L.) is a very important and widespread vegetable crop grown all around the world. It is on the list of 15 most commonly grown vegetables in the world (Best, 2000; Jahromi \& Amirizadeh, 2015). Onion is a monocot belonging to the family Alliaceae of the class Liliopsida, according to a classification by Takhtajan (Fritisch \& Friesen, 2002). Onion is a diploid $2 \mathrm{n}=16$, biennial plant originating from central Asia, i.e. Afghanistan, Iran, and Pakistan (Boukary et al., 2012). Bulb shape index is a significant biological and commercial trait. Bulb shape impacts the price on the market, proceeding process, disease resistance, etc. (Pavlović et al., 2007); therefore, it is a very important economical trait. Bulb shape index represents the ratio between height and bulb diameter. Bulb shape is a very important indicator for onion growing and breeding. This trait depends on genetic base (variety), impact of ecological factor and their interaction G x E (Grant \& Carter, 1997; Pavlović et al., 2000; Mehta et al., 2003; Haydar et al., 2007; Singh et al., 2010). The most important economical characteristics of onion bulbs, including the shape index, are polygene and in order to

Corresponding author: npavlovicpb@gmail.com

Acknowledgement:

Financial support for this research was provided by Ministry of Education, Science and Technological Development through grant TR31059. conduct a successful selection process, the onion collection should be as various as possible (Singh et al., 2010; Gvozdanović-Varga et al., 2013). Ratio structure of bulb shape index compared to other bulb traits has high genetic correlation with plant height, number of leaves, diameter, mass and yield of bulb, which was noted by Haydar et al. (2007) and Singh et al. (2010). Knowledge of correlation relations can greatly help the breeder in the proper selection of the breeding methods (Pavlović et al., 2007).

In order to make the proper choice of parental pairs so that their crossing gives positive response to breeding to bulb shape index, onion collections should be genetically assessed in details. The success of the selection depends on the genetic determination of traits that were targeted for the selection (Pavlović et al., 2015). Based on genetic parameters potential parental lines were chosen, which was the aim of this study.

\section{Material and Method}

In our study, divergent genotypes were selected (Pavlović, 1999), originating from different geographical positions. These genotypes originate from onion germplasm collection of the Institute for Vegetable Crops in Smederevska Palanka, Serbia. The method of diallel crossing without reciprocals was applied. The following varieties were studied: 'Makoi bronzi' (MB), 'Piroška' (PR), 'AC 101', 'Jasenički crveni' (JC), and 'Bunkino beo' (BB). 
The open field trial was set up in random block system with 5 repetitions with 30 plants in each repeat. Both parental lines and $F_{1}$ and $F_{2}$ generation of onion hybrids were included in this study. Plants were grown by applying standard growing technology. Heredity mode of onion shape index was evaluated by using test of significance of mean values of $F_{1}$ hybrids and $F_{2}$ generations comparing to parental average according to Borojević (1986). Segregation of genetic variance has been done by applying method of Hayman (1954) and Mather \& Jinks (1971), and the analysis of combination abilities has been done by method of Griffing (1956), method 2, mathematic model 1 , that includes $F_{1}$ and $F_{2}$ generation besides parents.

\section{Results and Discussion}

Form index of parental genotypes shows that there are representatives of almost all forms of onion bulbs. Line 'AC 101' belongs to flat, round-shaped bulb group, and the most of parental lines had round form of bulb ('Jasenički crveni', 'Piroška' and 'Makoi bronzi'), while 'Bunkino beo' was oval shaped (Table 1). Hybrid combinations of $F_{1}$ generation were flat-round shaped
('Piroška' $\times$ 'Bunkino beo') $(0.82 \%)$, to oval ('Makoi bronzi' $\times$ 'AC 101' and 'Makoi bronzi' $\times$ 'Jasenički crveni') (1.21\%, Table 17). In $F_{2}$ generation bulb shape index also varied from round-flat ('Piroška' $\mathrm{x}$ 'Bunkino beo') to oval ('Makoi bronzi' $\times$ 'AC 101') with highest coefficient $1.23 \%$. Variability expressed in variation coefficient $(\mathrm{Cv})$, in parental lines was from $6.05 \%$ for 'AC 101 ' to $10.54 \%$ for variety 'Piroška'. In $F_{1}$ generation, variability ranged from $5.16 \%$ ('Piroška' $\times$ 'Bunkino beo') to $6.30 \%$ ('Makoi bronzi' $\times$ 'AC 101'). Variability in $\mathrm{F}_{2}$ generation was higher and ranged from $6.36 \%$ to $14.62 \%$ (Table 1 ).

Similar values for variability of this analysed trait were reported by Pavlović et al. (2000). Agic Ruki (1996) reported that the average variation coefficient reached even $18.17 \%$. Similar values for variability of onion shape index were found by Pavlović et al. (2000), while the study of Agic Ruki (1996) proved that variation coefficient went up to $18.17 \%$. GvozdanovićVarga et al. (2013) found that onion shape index in varieties was uniformed with low percent of variation, while it was not so in the onion population. The most common heredity mode of onion bulb shape in our study was the domination. This heredity mode has been noted

Table 1. Mean value/transformed $(\overline{\mathrm{X}})$, standard error $(\mathrm{Sx})$, variation coefficient $(\mathrm{Cv})$, heredity mode, the absolute and relative heterosis $\left(\mathrm{Ha}\right.$ and $\mathrm{Hr}$ ) for bulb shape index of the researched variety, $\mathrm{F}_{1}$ and $\mathrm{F}_{2}$ onion hybrids

\begin{tabular}{|c|c|c|c|c|c|c|c|c|}
\hline \multirow[b]{2}{*}{ Genotype } & \multicolumn{2}{|c|}{$\mathrm{F}_{1}$} & \multicolumn{2}{|c|}{$\mathrm{F}_{2}$} & \multicolumn{2}{|c|}{$\mathrm{Ha}$} & \multicolumn{2}{|c|}{$\mathrm{Hr}$} \\
\hline & $\begin{array}{c}\bar{x} \\
\pm S x\end{array}$ & $\mathrm{CV}_{(\%)}$ & $\begin{array}{c}\bar{x} \\
\pm S x\end{array}$ & $\mathrm{CV}_{(\%)}$ & $\mathrm{F}_{1}$ & $\mathrm{~F}_{2}$ & $\mathrm{~F}_{1}$ & $\mathrm{~F}_{2}$ \\
\hline$M B \times P R$ & $\begin{array}{l}1.11 / 6.02 \\
1.27\end{array}$ & 8.31 & $\begin{array}{l}1.11 / 6.02 \\
1.27\end{array}$ & 8.31 & & & & \\
\hline MB x AC 101 & $\begin{array}{l}1.20 / 6.29 \\
1.07\end{array}$ & 3.90 & $\begin{array}{l}1.20 / 6.30 \\
0.92\end{array}$ & 7.94 & $0.41^{* *}$ & $0.42^{*}$ & 6.97 & 7.08 \\
\hline $\mathrm{MB} \times \mathrm{JC}$ & $\begin{array}{l}1.21 / 6.30 \\
0.70 \mathrm{Sd}+\end{array}$ & 5.08 & $\begin{array}{l}1.23 / 6.30 \\
1.52^{\mathrm{SD}+}\end{array}$ & 9.61 & $0.80^{* *}$ & $0.80^{* *}$ & 14.62 & 14.62 \\
\hline $\mathrm{MB} \times \mathrm{BB}$ & $\begin{array}{l}1.21 / 6.29 \\
1.46 \mathrm{Sd}+\end{array}$ & 2.81 & $\begin{array}{l}1.20 / 6.30 \\
2.23\end{array}$ & 11.43 & $0.47^{* *}$ & $0.47^{*}$ & 8.07 & 8.12 \\
\hline PR x AC 101 & $\begin{array}{l}0.915 .55 \\
0.49 \text { Sd- }\end{array}$ & 5.59 & $\begin{array}{l}0.885 .39 \\
3.25^{\text {SD- }}\end{array}$ & 13.14 & $-0.74^{* *}$ & $-0.90^{* *}$ & -11.74 & -14.29 \\
\hline PR x JC & $\begin{array}{l}1.03 / 5.74 \\
2.07\end{array}$ & 10.54 & $\begin{array}{l}1.03 / 5.74 \\
2.07\end{array}$ & 10.54 & & & & \\
\hline$P R \times B B$ & $\begin{array}{l}1.13 / 6.04 \\
1.11 \mathrm{Sd}+\end{array}$ & 3.50 & $\begin{array}{l}1.13 / 6.06 \\
0.56 \mathrm{SD}+\end{array}$ & 6.36 & $0.69^{* *}$ & $0.67^{* *}$ & 12.82 & 12.51 \\
\hline AC $101 \times \mathrm{JC}$ & $\begin{array}{l}1.00 / 5.74 \\
0.59\end{array}$ & 6.36 & $\begin{array}{l}1.05 / 5.74 \\
2.38\end{array}$ & 11.32 & 0.06 & 0.06 & 1.05 & 0.99 \\
\hline AC $101 \times$ BB & $\begin{array}{l}0.82 / 5.16 \\
0.66 \mathrm{Sd}-\end{array}$ & 6.20 & $\begin{array}{l}0,845.26 \\
3.89 \text { SD- }\end{array}$ & 14.62 & $-0.98^{* *}$ & $-0.89^{* *}$ & -16.02 & -14.40 \\
\hline $\mathrm{JC} \times \mathrm{BB}$ & $\begin{array}{l}0.75 / 4.97 \\
0.65\end{array}$ & 6.05 & $\begin{array}{l}0,75 / 4.97 \\
0.65\end{array}$ & 6.05 & & & & \\
\hline AC $101 \times \mathrm{JC}$ & $\begin{array}{l}1.11 / 6.02 \\
1.62 \mathrm{Sd}+\end{array}$ & 2.12 & $\begin{array}{l}1,13 / 6.02 \\
1.60^{\mathrm{SD}+}\end{array}$ & 9.59 & $0.72^{* *}$ & $0.73^{* *}$ & 13.59 & 13.71 \\
\hline AC $101 \times$ BB & $\begin{array}{l}1.00 / 5.74 \\
0.51^{\mathrm{i}}\end{array}$ & 5.65 & $\begin{array}{l}1,03 / 5.74 \\
2.46^{1}\end{array}$ & 11.52 & -0.02 & -0.02 & -0.37 & -0.31 \\
\hline Jasenički crveni (JC) & $\begin{array}{l}0.97 / 5.63 \\
1.72\end{array}$ & 9.52 & $\begin{array}{l}0,97 / 5.63 \\
1.72\end{array}$ & 9.52 & & & & \\
\hline $\mathrm{JC} \times \mathrm{BB}$ & $\begin{array}{l}0.87 / 5.35 \\
1.08 \mathrm{Sd}-\end{array}$ & 2.83 & $\begin{array}{l}1,06 \sqrt{5.35} \\
1.97 \mathrm{SD}-\end{array}$ & 9.91 & $0.72^{* *}$ & $-0.74^{* *}$ & -12.12 & 12.12 \\
\hline Bunkino beo (BB) & $\begin{array}{l}1.34 / 6.55 \\
0.58\end{array}$ & 6.18 & $\begin{array}{l}1,34 / 6.55 \\
0.58\end{array}$ & 6.18 & & & & \\
\hline & $\begin{array}{l}0.05=0.29 \\
0.01=0.38\end{array}$ & $\begin{array}{r}\mathrm{F}_{2} \mathrm{LSD}_{0} \\
\mathrm{LSD}_{0}\end{array}$ & $\begin{array}{l}0.42 \\
0.56\end{array}$ & & & & & \\
\hline
\end{tabular}


in 7 hybrid combinations of $F_{1}$ generation and only one combination had intermediate heredity (Table 1).

$\mathrm{F}_{2}$ generation had different results. Superdomination of the better parent appeared in three combinations, super-domination of the worse parent also appeared in three combinations, and in one combination the intermediate heredity was found (Table 1). All studied combinations had three hybrid combinations with negative heterosis, while all other had positive values. In $F_{1}$ generation 8 hybrid combinations had very significant heterosis, while in two combinations heterosis was significant (Table 1).

The largest part of genetic variance for bulb shape index belongs to additive gene action. Additive component (D) was higher than dominant $\left(\mathrm{H}_{1}\right.$ and $\left.\mathrm{H}_{2}\right)$ in both generation values (Table 2). In support of this statement is the fact that the positive values of $F$ (interaction additive $\mathrm{x}$ dominant effect), which proves that dominant genes participate in heredity of these traits. Dominant and recessive alleles were not equally staggered since the value $\mathrm{H}_{2} / 4 \mathrm{H}_{1}$ was 0.22 and 0.15 . Heritability in $\mathrm{F}_{1}$ hybrid generation was 0.18 in broad and 0.94 in wide sense. Values for heritability in $F_{2}$ generation were a little lower (Table 2). High values for heritability index of bulb shape prove that this trait is mainly determined by genetic base. High values of heritability in wide sense were very useful in selection to phenotype performances (Singh et al., 2010).

Ratio of total number of dominant and recessive alleles for all parents $(\mathrm{Kd} / \mathrm{Kr})$ shows that dominant were more numerous than recessive alleles, since that ratio was

Table 2. Components of genetic variance for bulb shape index

\begin{tabular}{ccc}
\hline Components & $\mathrm{F}_{1}$ values & $\mathrm{F}_{2}$ values \\
\hline$D$ & 0.324 & 0.125 \\
$H_{1}$ & 1.039 & 0.207 \\
$H_{2}$ & 0.621 & 1.085 \\
$F$ & 0.667 & 0.124 \\
$E$ & 0.010 & 0.022 \\
$H_{2} / 4 H_{1}$ & 0.149 & 0.225 \\
$\sqrt{H_{1} / D}$ & 1.791 & 3.109 \\
$K d / K r$ & 3.705 & 1.378 \\
$b u^{2}$ & 0.94 & 0.93 \\
$b s^{2}$ & 0.18 & 0.17 \\
\hline
\end{tabular}

higher than 1 (Table 2). The value $\sqrt{H_{1} / D}=3.10$ and 1.79 , points to average domination, and in our study it was higher than 1 , which proves that in heredity of bulb shape index it's about super domination, bearing in mind all crossing combinations. Data in Table 3 prove that there were highly significant differences for GCA as well as for SCA. Ratio GCA/SCA proves that additive component was 0.5 and 0.6 times lower than non additive. Two parental lines had significant GCA (Table 4). The highest GCA for shape index was found in variety 'Makoi bronzi', which is considered to be the reflection of best combining abilities. Other parents in this trial had mostly negative values of general combination abilities for the studied trait (Table 4). In $\mathrm{F}_{2}$ generation, the highest value of GCA was found in variety 'Bunkino beo'.

The highest positive value of SCA in $\mathrm{F}_{1}$ generation comparing to other crossing was found in combination 'Makoi bronzi' $\times$ 'AC 101'. Besides that, the significant positive value was found in two crossing combinations. In $F_{2}$ generation, the highest value was found in combination 'Jasenički crveni' $\times$ 'Bunkino beo' (Table 5). Almost uniformed number of crossing with positive and negative SCA values was the consequence of equal impact of additive and non-additive genetic variance in inheriting the bulb shape index.

The regression coefficient in $\mathrm{F}_{1}$ generation was not significantly different from 1 , which proves the absence of inter-allele interaction. However, in $\mathrm{F}_{2}$ generation inter-allele gene interaction was present in inheriting onion bulb shape index.

The regression coefficient in $\mathrm{F}_{1}$ generation was not significantly different from 1 , which proves the absence of inter-allele interaction. However, in $\mathrm{F}_{2}$ generation inter -allele gene interaction was present in inheriting onion bulb shape index.

According to the given Figures 1 and 2, the regression line was away from the limiting parabola, which proves that the impact of the non-additive genes was higher. Crossing of the expected regression line with $\mathrm{Wr}$ axis was above the coordinate start, which proves the partial domination as the mode of inheriting this trait (Figures 1 and 2). Point disposition in the diagram and its dispersion along the expected regression line prove that the parental genotypes were divergent to the bulb shape index.

Parental line with highest number of dominant genes for the researched trait in $F_{1}$ generation was 'Jasenički crveni', while in $\mathrm{F}_{2}$ generation almost

Table 3. Analysis of variance of combination abilities for bulb shape index

\begin{tabular}{|c|c|c|c|c|c|c|c|}
\hline \multirow[t]{2}{*}{ Source of variation } & \multirow[t]{2}{*}{ Level of freedom } & \multicolumn{2}{|c|}{ Sum of squares (SS) } & \multicolumn{2}{|c|}{ The middle squares (MS) } & \multicolumn{2}{|c|}{ F-exp } \\
\hline & & $\mathrm{F}_{1}$ & $\mathrm{~F}_{2}$ & $\mathrm{~F}_{1}$ & $\mathrm{~F}_{2}$ & $\mathrm{~F}_{1}$ & $\mathrm{~F}_{2}$ \\
\hline GCA & 4 & 0.45 & 0.76 & 0.11 & 0.19 & $11.26^{* *}$ & $8.52^{* *}$ \\
\hline SCA & 10 & 2.21 & 3.07 & 0.22 & 0.30 & $21.76^{* *}$ & $13.75^{* *}$ \\
\hline Error & 28 & & & 0.01 & 0.02 & & \\
\hline GCA/SCA & & & & 0.52 & 0.62 & & \\
\hline $\begin{array}{l}\text { GCA } F_{0.05}= \\
\text { SCA } F_{0.05}=\end{array}$ & $\begin{array}{l}F_{0.01}=4.0 \\
F_{0.01}=3.0\end{array}$ & & & & & & \\
\hline
\end{tabular}


equally, those were variety 'Piroška' and 'Makoi bronzi'. Bearers of the largest number of the recessive genes for the bulb shape index in $F_{1}$ generation were varieties
'Bunkino beo' and 'AC 101', while in $\mathrm{F}_{2}$ generation the variety 'Bunkino beo' clearly stood out (Figure 2).

Table 4. GCA value of parental lines for bulb shape index

\begin{tabular}{|c|c|c|c|c|c|c|}
\hline Parents & $\begin{array}{l}\mathrm{GCA} \mathrm{F}_{1} \\
\text { value }\end{array}$ & Range & $\mathrm{Se}$ & $\begin{array}{c}\mathrm{GCA} \mathrm{F}_{2} \\
\text { Value }\end{array}$ & Range & $\mathrm{Se}$ \\
\hline $\mathrm{MB}$ & $0.202^{* *}$ & 1 & & 0.013 & 3 & \\
\hline PR & -0.048 & 5 & & -0.129 & 4 & \\
\hline AC 101 & $-0.146^{* *}$ & 4 & 0.053 & $-0.205^{*}$ & 5 & 0.079 \\
\hline $\mathrm{JC}$ & -0.020 & 3 & & 0.152 & 2 & \\
\hline $\mathrm{BB}$ & 0.013 & 2 & & $0.165^{*}$ & 1 & \\
\hline $\begin{array}{l}\operatorname{LSD}_{0.05}= \\
\operatorname{LSD}_{0.01}=\end{array}$ & $\begin{array}{l}0.107 \\
0.143\end{array}$ & & & $\begin{array}{l}\mathrm{LSD}_{0.05}=0.159 \\
\mathrm{LSD}_{0.01}=0.212\end{array}$ & & \\
\hline
\end{tabular}

Table 5. Value SCA $F_{1}$ and $F_{2}$ generation for bulb shape index

\begin{tabular}{lccc}
\hline Genotype & SCA F $_{1}$ & Se & SCA F \\
\hline MB x PR & $0.294^{*}$ & & 0.292 \\
MB x AC 101 & $0.399^{* *}$ & & $0.366^{*}$ \\
MB x JC & $0.269^{*}$ & 0.010 \\
MB x BB & $-0.510^{* *}$ & $-0.608^{* *}$ & 0.178 \\
PR x AC 101 & $0.393^{* *}$ & 0.120 & 0.329 \\
PR x JC & -0.029 & -0.213 \\
PR x BB & $-0.646^{* *}$ & $-0.545^{* *}$ \\
AC 101 x JC & $0.342^{* *}$ & 0.047 \\
AC 101 x BB & 0.028 & -0.151 \\
JC x BB & -0.234 & LSD $_{0.05}=0.357$ \\
\hline Se - standard error & LSD $_{0.01}=0.320$ & LSD $_{0.01}=0.475$ \\
\end{tabular}

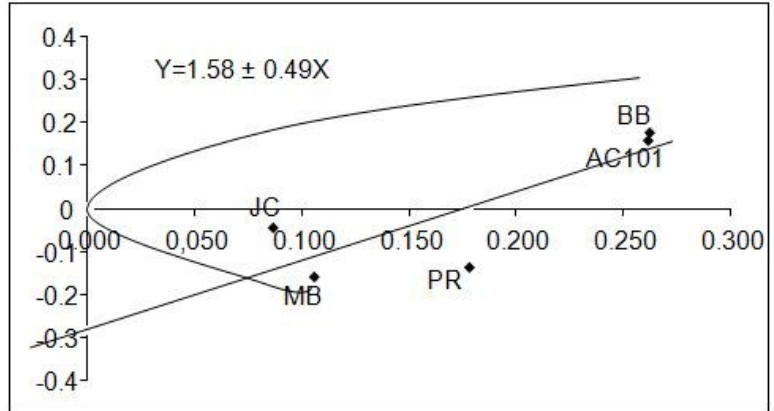

Figure 1. VrWr regression for average bulb shape index in $\mathrm{F}_{1}$ generation

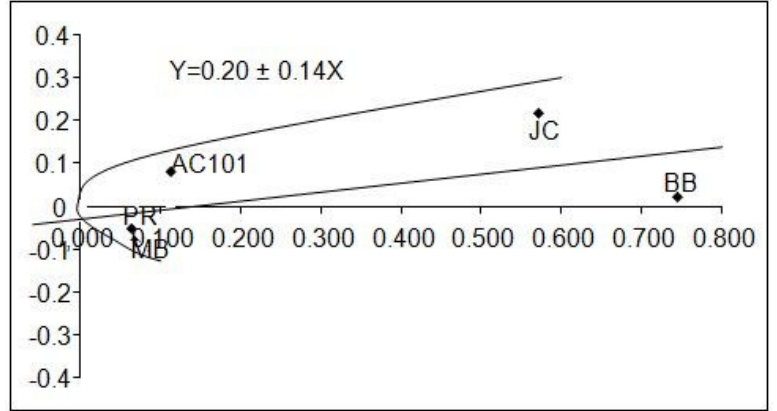

Figure 2. $\mathrm{VrWr}$ regression for average bulb shape index in $\mathrm{F}_{2}$ generation 


\section{Conclusion}

In analysing the onion bulb shape index in our study, almost all known bulb shapes were studied. Bulb shapes in $F_{1}$ and $F_{2}$ generations were from flat-round to oval. The highest value of GCA for bulb shape index was found in variety 'Makoi bronzi', which proves it has the best combining abilities. The highest value of SCA in $F_{1}$ and $F_{2}$ generations was found in hybrid 'Makoi bronzi' $\times$ 'AC 101'.

\section{References}

Agic, R. (1996). Sporedbeni ispituvana introduirani poluluti sorti kromid vo uslovi na skopsko. Master thesis, Zemjodelski fakultet, Skopje, Makedonija.

Best, K. (2008). Red onion cultivars trial. Horticultural Nova Scotia, Kentville agricultural centre, Nova Scotia, Canada.

Borojević, K. (1986). Genes and Population (in Serbian). Novi Sad: Forum.

Boukary, H., Haougui, A., Barage, M., Adam, T., Roumba, A., \& Saadou, M. (2012). Evaluation agro-morphologique des varietes et/ou ecotypes locaux d'oignon du Niger. Int J Biol Chem Sci, 6 (6), 3098-3106.

Fritisch, R. M., \& Friesen, N. (2002). Evolution, domestication and taxonomy. In H. D. Rabinowitch and L. Currah (Eds.), Allium Crop Science: Recent Advances (pp. 5-27). CAB International.

Grant, D. G., \& Carter, B. V. (1997). The influence of cultural factors on the bulb shape of the onion (Allium cepa L.) cultivar »Pukekohelv Longkeeper«. Acta. Hort., 433, 527-532.

Griffing, B. (1956). Concept of general and specific combining ability in relation to diallel crossing systems. Aust. J. Biol. Sci., 9, 463-493.
Gvozdanović-Varga, J., Vasić, M., Červenski, J., Petrović, A., \& Moravčević, Đ. (2013). Phenotypic diversity of basic characteristics of genotypes from the Serbia onion collection. Genetika, 45(1), 1101-1108.

Hayder, A., Sharker, N., Ahmed, M. B., Hannan, M. M., Razvy, M. A., Hossain, M., Hoque, A., \& Karim, R. (2007). Genetic variability and interrelationship in onion (Allium cepa L.). Middle-East Journal of Scientific Research, 2(3-4), 132-134.

Hayman, B. J. (1954). The theory and analysis of diallel crosses. Genetics, 39, 787-809.

Jahromi, A. A., \& Amirizadeh, R. S. (2015). Production potential of onion (Allium cepa L.) as influenced by different transplant ages. Indian Journal of Fundamental and Applied Life Sciences, 5(2), 118121.

Mather, K., \& Jinks, J. L. (1971). Biometrical Genetics. (2nd edition). London: Champan and Hall.

Mehta, D. R., Golani, I. J., Vaddoria, M. A., \& Dobariya, K. L. (2003). Stability analysis for bulb yield and its attributes in onion. Vegetable Science, 30(1), 33-36.

Pavlović, N., Zdravković, J., \& Mijatović, M. (2007). Genetic and phenotypic correlation of some onion (Allium cepa L.) bulb traits. Proceedings of the Third Balkan Symposium on Vegetable and Potatoes, Bursa, Turkey. Acta Horticulturae, 729, 57-60.

Pavlović, N., Momirović-Šurlan, G., Cvikić, D., \& Sušić, Z. (2000). Varijabilnost i koeficijent heritabilnosti indeksa oblika lukovica crnog luka. Knjiga izvoda III JUSEM, 48.

Pavlović, N., Cvikić, D., Zdravkovic, J., Đorđević, R., Zdravković, M., Gvozdanović-Varga, J., \& Moravčević, Đ. (2015). Heredity mode of onion (Allium cepa L.) bulb fresh weight. Ratar. Povrt., 52 (1), 24-28.

Pavlović, N. (1999). Ocena selekcione vrednosti i divergentnosti germplazme u kolekciji crnog luka (Allium cepa L.). Master thesis, University of Belgrade, Faculty of Agriculture.

Singh, R. K., Dubey, B. K., Bhonde, S. R., \& Gupta, R. P. (2010). Variability studies for some quantitative characters in white onion (Allium cepa L.) advances lines. Vegetable Science, 37(1), 105107.

\section{Način nasleđivanja indeksa oblika lukovice crnog luka (Allium cepa L.)}

\section{Nenad Pavlović · Milan Zdravković · Jelica Gvozdanović-Varga · Jelena Mladenović · Radoš Pavlović · Jasmina Zdravković}

Sažetak: Crni luk (Allium cepa L.) je izuzetno važna i široko raspostranjena povrtarska vrsta. Indeks oblika lukovice crnog luka predstavlja veoma značajno biološko i tržišno svojstvo. Oblik lukovica ima uticaja na tržišnu cenu crnog luka, proces dorade, otpotnost na bolesti, itd. Zbog ovoga, indeks oblika se ubraja u važnu ekonomsku osobinu lukovice crnog luka. Genetska determinisanost osobine utiče na uspešnost procesa selekcije. Kako bi utvrdili genetsku determinisanost indeksa oblika lukovice, postavljen je ogled po slučajnom blok sistemu u pet ponavljanja. Primenjen je metod dialelnog ukrštanja bez recipročnog. Posmatrajući hibridne kombinacije $\mathrm{F}_{1}$ generacije može se uočiti da se njihov indeks oblika lukovice kretao od pljosnato-okruglog do ovalnog. Najzastupljeniji način nasleđivanja indeksa oblika lukovice u ovom istraživanju je super dominacija. Najveću vrednost OKS za indeks oblika imala je linija 'Makoi bronzi'. Najvišu vrednost za PKS u F $F_{1}$ i $F_{2}$ generaciji imao je hibrid dobijen ukrštanjem linije 'Makoi bronzi' × 'AC 101'.

Ključne reči: crni luk, indeks oblika lukovice, način nasleđivanja 